\title{
ESTOPPEL AGAINST JURISDICTIONAL ATTACK ON DECREES OF DIVORCE
}

\section{HOMER GLARK $\dagger$}

As a general principle a court's judgment given without jurisdiction over the subject matter of the action is void and open to collateral attack, ${ }^{1}$ either by the parties to the original suit ${ }^{2}$ or by others whose interests may have been affected thereby. ${ }^{3}$ This principle governs divorce decrees as well as other kinds of decrees and judgments, ${ }^{4}$ perhaps with even greater force because of the state's often mentioned interest in divorces. Yet there has long been another conflicting principle, that one who obtains a judgment cannot later collaterally attack it upon jurisdictional grounds. ${ }^{5}$ This principle also has long been applied to divorce decrees, ${ }^{6}$ (though not without some disagreement), and recently has been rather broadly extended. ${ }^{7}$ This second principle is commonly referred

$\dagger$ Professor of Law, University of Colorado, School of Law.

1. Restatement, Judgments $\$ \S 5,7,11$ (1942); 1 Freeman, Judgments $\$ \$ 333,337$ (5th ed. 1925) ; Note, Developments in the Law of Res Judicata, 65 HARv. L. REv. 818, 851, 853 (1952) ; see Baltimore Mail S.S. Co. v. Fawcett, 269 N.Y. 379, 390, 199 N.E. 628 , 633, ccrt. denicd, 298 U.S. 675 (1936). The principle is limited today by res judicata. See Bosky \& Braucher, Jurisdiction and Collateral Attack, 40 Colum. L. Rev. 1006 (1940); REsTatenent, Judgrents $\$ 10$ (1942). It may also be limited by the requirement that the lack of jurisdiction must appear on the face of the record. 1 FreEman, op. cit. supra $\$ 333$.

2. 1 id. $\S 317$.

3. 1 id. $\S 318$.

4. Jacobs, Attack on Decrees of Divorce, 34 Micr. L. Rev. 749 (1936), reprinted in Association of American Law Schools, Selected Essays on Family Law 987 (1950) ; Note, Stranger Attack on Sister-State Decrees of Divorce, 24 U. CEr. L. Rev. 376 (1957). For an example of the rigid treatment of jurisdiction, see People v. Dawell, 25 Mich. 247 (1872) (Cooley, J.).

5. Relatively few early cases outside the divorce field have been found to support this proposition. A clear statement of it is found in 3 STORY, Equity JuRISPRudence 581 (14th ed. 1918), and 1 FreEMaN, op. cit. supra note 1 , \$ 320. 'Cases which do support it are Three States Lumber Co. v. Blanks, 133 Fed. 479 (6th Cir. 1904); Consolidated Home Supply Ditch \& Reservoir Co. v. New Loveland \& Greeley Irr. \& Land Co., 27 Colo. 521, 62 Pac. 364 (1900) ; Ray v. McLain, 106 La. 780, 31 So. 315 (1901); Hewitt v. Northrup, 75 N.Y. 506, 510 (1878).

6. E.g., Palmer v. Palmer, 1 Sw. \& Tr. 551, 164 Eng. Rep. 855 (Ct. for Div. and Matrim. Causes 1859); Ellis v. White, 61 Iowa 644, 17 N.W. 28 (1883). Cases contra often turned on the argument that the application of estoppel would in effect allow spouses to confer jurisdiction and obtain divorces by consent alone. See Smith v. Smith, 79 Mass. (13 Gray) 209 (1859).

Other cases on this point are collected in the following annotations: 60 I.R.A. 294, 301 (1902); 51 L.R.A. 534 (1914); 109 A.L.R. 1018, 1019 (1937) ; 122 A.L.R. 1321, 1323 (1939); 140 A.L.R. 914, 915 (1942); 152 A.L.R. 941, 943 (1944); 175 A.L.R. 538, 539 (1948).

7. The extension is nicely illustrated by the successive changes in the Restatement of the Conflict of Laws. The original Restatement, § 112, in 1934 stated that "the validity 
to as "estoppel." For convenience it will be so named here, although it sometimes differs from technical equitable estoppel. The latter estoppel is usually defined as the doctrine that one who has taken a position with reference to a transaction and thereby obtained a benefit or brought about a change of position in the other party to the transaction cannot later take an inconsistent position which would prejudice the other party. ${ }^{8}$

One application of estoppel to divorce decrees is to be distinguished. ${ }^{9}$ Sherrer $v$. Sherrer ${ }^{10}$ held that if a state which granted a divorce would deny collateral attack upon it because the defendant had had an opportunity to raise and litigate the question of jurisdiction over the subject matter by having been made subject to the court's in personam jurisdiction, then other states must also refuse to entertain collateral attacks upon the same grounds. Sherrer thus announced a principle of full faith and credit whose application depends upon the rule of res judicata adopted in the state granting the divorce. The policy underlying this rule is that which demands finality in litigation after a person has had a chance to present his case. As will appear, the policy underlying the kind of estoppel presently under discussion is different. Both doctrines preciude attack on admittedly invalid divorces, but for different reasons.

Logically it would seem that if the full-faith-and-credit clause ${ }^{11}$ requires that a foreign state respect the doctrines of res judicata of the divorcing state, it should likewise require that the foreign state respect the various other rules of estoppel prevailing in the divorcing state. So, if on a theory of estoppel the divorcing state would exclude collateral attack upon its own decree by the party who obtained it, the full-faith-and-credit clause should forbid a similar attack in other states. But in spite of the apparently logical analogy, this is

of a divorce decree cannot be questioned ... either by a spouse who has obtained such decree of divorce from a court which had no jurisdiction, or by a spouse who takes advantage of such decree by remarrying." A caveat was included, expressing no view on whether a spouse might be precluded from questioning the validity of a divorce for other reasons. In the 1948 supplement to the Restatement of the Conflict of Laws, the caveat was removed, and the following language was added in comment $(c)$ to $\$ 112$ : "Any person may be precluded from questioning the validity of a divorce decree if, under all the circumstances, his conduct has led to the obtaining of the divorce decree, or for any other reason has been such as to make it inequitable to permit him to deny the validity of the divorce decree." Finally, the 1953 Tentative Draft No. 1 of the Restatement of the Conflict of Lawes completely revises $\S 112$, so as to make it read: "A person may be precluded from questioning the validity of a divorce decree if, under the circumstances of the case, it would be inequitable to permit him to do so."

8. Equitable estoppel is defined variously. See McCirnTock, EQurry 79 (2d ed. 1948). See also 3 Pomeroy, Equity Jurisprudence 189 (5th ed. 1941); Bigelow, EsTOPPEL 607 (6th ed. 1913). Short historical sketches of the origins of estoppel can be found in 9 HoLDSWORTH, HISTORY of ENGLISH LAW 161 (1926) ; 3 PoMrRY, op. cit. supra at 179.

9. This is usually referred to as "estoppel by judgment."

10. 334 U.S. 343 (1948).

11. U.S. Const. art. IV, $\S 1$. 
not the law. ${ }^{12}$ The reason lies in the difference between res judicata and the variation on equitable estoppel involved in divorce cases. The application of res judicata depends upon the conditions under which the divorce was granted and is really a function of the divorce decree itself. The estoppel under discussion here, however, is an equity principle dependent upon events which may have occurred after the divorce was granted or apart from the divorce action. It is not a function of the decree but a personal disability of the party attacking the decree. It is not a rule of jurisdiction. Therefore its application is not governed by the full-faith-and-credit clause.

Under what circumstances, then, will courts invoke or refuse to invoke estoppel? After an enumeration of them an attempt can be made to determine the bases and extent of the doctrine.

The circumstances which most obviously calls for application of the estoppel theory is that the divorce was obtained by the very party attempting to attack it. The divorce plaintiff is usually held estopped to question the decree. ${ }^{13}$ The courts which reach this result are careful not to say that such divorces are valid, but say rather that the attacking party is estopped to assert that they are invalid. In fact, one court held that a husband could not assert the invalidity of his divorce from his first wife even after an annulment suit brought by his second wife had established that the divorce was void.14 What is probably the utmost extension of the estoppel doctrine occurred in an Ohio case which held that a wife who falsely told her husband she had divorced him was estopped to deny that she had, after he had remarried on the faith of her statement. ${ }^{15}$ This is divorce by consent with a vengeance, but it does fit the usual requirements for technical equitable estoppel. Sometimes

12. See Restatement, Conflict of Laws $\$ 112$, comment $a$ (Tentative Draft No. 1, 1953):

Unlike the principle of res judicata, mentioned in $\$ 111 \mathrm{a}$, application of this estoppel doctrine is not required by any constitutional mandate. The doctrine is determined in each case, not by the law of the state which granted the divorce, but by the law of the state in which the divorce is questioned. Each State of the United States is therefore free, at least within broad limits, to determine the doctrine's scope and range of effect.

The Restatement does not say what is meant by the qualification "at least within broad limits." See Gaylord v. Gaylord, 45 So. $2 d 507$ (Fla. 1950); Astor v. Astor, 160 N.Y.S.2d 103 (Sup. Ct. 1957) ; cf. Sutton v. Leib, 342 U.S. 402 (1952) (allowed Illinois to make its own determination as to whether an ex-wife had a continued right to alimony after contracting a void second marriage). An excellent discussion of this case can be found in Storke, Anmulment in the Conflict of Laws, 43 MINN. L. REv. 849, 860 (1959).

13. E.g., Cohen v. Randall, 137 F.2d 441 (2d Cir. 1943) (applying New York law); Curry v. Curry, 79 F.2d 172 (D.C. Cir. 1935); Oberstein v. Oberstein, 217 Ark. 80, 228 S.W.2d 615 (1950); Rediker v. Rediker, 35 Cal. 2d 796, 221 P.2d 1 (1950) ; Krause v. Krause, 282 N.Y. 355, 26 N.E.2d 290 (1940), 27 VA. L. REv. 118, 18 N.Y.U.L. REv. 94, 15 ST. Jorn's L. Rev. 107 (1940) ; Starbuck v. Starbuck, 173 N.Y. 503, 66 N.E. 193 (1903); Romanski Estate, 354 Pa. 261, 47 A.2d 233 (1946).

14. Watson v. Watson, 39 Cal. 2d 305, 246 P.2d 19 (1952).

15. Edgar v. Richardson, 33 Ohio St. 581 (1878). 
the defense of connivance may be used to reach the result ordinarily achieved through estoppel. ${ }^{16}$

Obtaining the decree does not estop the wife from questioning it, however, where she brought the divorce action as the result of the coercion, duress or fraud of her husband, ${ }^{17}$ or where for other reasons she cannot be held responsible for her actions. ${ }^{18}$

Participation in obtaining the divorce, as by persuading a married person to divorce his spouse, ${ }^{19}$ or by financing a married woman's divorce with the intention of marrying her, ${ }^{20}$ also has been held to estop one from a later collateral attack on the decree. If participation takes the form of an appearance in the case as defendant, then of course the Sherrer rule would immunize the resulting divorce from attack on the basis of res judicata, ${ }^{21}$ although the cases occasionally use the language of estoppel here. ${ }^{22}$

Estoppel may also rest upon acts or events occurring after the divorce in question. A long acquiescence in the divorce with knowledge of its jurisdictional defect will often foreclose an attack, whether the rationale of the defense is labeled estoppel or laches. ${ }^{23}$

Acceptance of benefits, usually alimony, under the divorce has the same

16. Shilman v. Shilman, 105 Misc. 461, 174 N.Y. Supp. 385 (Sup. Ct. 1918), aff'd withont opinion, 188 App. Div, 908, 175 N.Y. Supp. 681 (1919), aff'd without opinion, 230 N.Y. 554, 130 N.E. 890 (1920). Here the husband had obtained a Jewish divorce, after which the wife remarried. He then sued her for divorce on the ground of adultery and the court held him barred by his connivance. See also Langewald v. Langewald, 234 Mass. 269, 125 N.E. 566 (1920); Loud v. Loud, 129 Mass. 14 (1880).

17. Meyer v. Meyer, 328 I1I. App. 408, 66 N.E.2d 457 (1946) ; Burton v. Burton, 176 Okla. 494, 56 P.2d 385 (1936); Graham v. Graham, 54 Wash. 70, 102 Pac. 891 (1909) (semble).

18. Meyer v. Meyer, 328 Ill. App. 408, 66 N.E.2d 457 (1946) (wife in a sanatorium for alcoholism).

19. Goodloe v. Hawk, 113 F.2d 753 (D.C. Cir. 1940) (overruling Simmons v. Simmons, 19 F.2d 690 (D.C. Cir. 1927)) ; Bowen v. Finke, 34 F. Supp. 235 (D.D.C. 1940); Margulies v. Margulies, 109 N.J. Eq. 391,157 Atl. 676 (Ch. 1931) ; Packer v. Packer, 6 App. Div, 2d 464, 179 N.Y.S.2d 801 (1958). See also Saul v. Saul, 122 F.2d 64 (D.C. Cir. 1941). Contra, Jardine v. Jardine, 291 Ill. App. 152, 9 N.E.2d 645 (1937) ; Golden v. Golden, 41 N.M. 356, 68 P.2d 928 (1937) (Mexican divorce); Nimmer's Estate v. Nimmer, 212 S.C. 311, 47 S.E.2d 716 (1948) (both parties at fault).

20. In re Coleman's Estate, 132 Cal. App. 2d 137, 281 P.2d 567 (Dist. Ct. App. 1955).

21. See note 10 supra.

22. E.g., Green v. Green, 77 Ariz. 219, 269 P.2d 718 (1954).

23. E.g., In re Shank's Estate, 154 Cal. App. 2d 808, 316 P.2d 710 (Dist. Ct. App. 1957) ; Swift v. Swift, 239 Iowa 62, 29 N.W.2d 535 (1947) (defect here consisted of absence of proper services; laches held to operate against the husband, the innocent party) ; Zirkalos v. Zirkalos, 326 Mich. 420, 40 N.W.2d 313 (1949) (husband estopped to question wife's divorce from prior marriage after six-year acquiescence with knowledge of facts). New York's five-year statute of limitations applicable to adultery reaches a similar result. N.Y. Crv. Prac. Acr $\$ 1153$, as construed by Ackerman v. Ackerman, 200 N.Y. 72, 93 N.E. 192 (1910). Contra, Tariton v. Tariton, 262 Ala. 67, 77 So. $2 d 347$ (1955) (no laches or estoppel where the complaining party did not know the facts). 
consequence. ${ }^{24}$ Remarriage after the defective decree, either by the person attacking it ${ }^{25}$ or by the other party, ${ }^{26}$ will usually raise an estoppel, as will reliance upon the decree by innocent third parties. ${ }^{27}$ At this point estoppel to attack a defective divorce begins to resemble estoppel to attack a defective marriage, since both arise from courts' reluctance to upset relationships formed (by one party at least) in good faith and in ignorance of any defect. ${ }^{28}$

This summary of the kinds of cases in which courts have rejected attacks upon invalid divorce decrees is evidence of a broad acceptance of the estoppel doctrine. If a mere counting of cases were not irrelevant, or even misleading, one might sum up by saying that the majority of jurisdictions approve of estoppel in this context and let the matter rest there. Nevertheless, the cases which do not approve are numerous enough and of sufficient standing as authorities to require further discussion of the basis and extent of the doctrine. The confusion which is found within particular jurisdictions such as New York also demands some clarification. An attempt to bring some order to the subject is therefore not to be shirked.

One rationale, originating in New York ${ }^{29}$ and seized upon with relief by troubled judges in other states, ${ }^{30}$ makes the application of estoppel turn upon the nature of the lawsuit, once facts which might justify estoppel are found to be

24. E.g., Anderson v. Anderson, 223 Ark. 571, 267 S.W.2d 316 (1954); Langewald v. Langewald, 234 Mass. 269, 125 N.E. 566 (1920) ; Norris v. Norris, 342 Mich. 83, 69 N.W.2d 208, cert. denied, 350 U.S. 903 (1955).

25. E.g., Dietrich v. Dietrich, 41 Cal. 2d 497, 261 P.2d 269 (1953), cert. denied, 346 U.S. 938 (1954) ; Norris v. Norris, supra note 24; Cummings v. Huddleston, 99 Okla. 195, 226 Pac. 104 (1924). See also 2 Brshop, Marriage and Divorce § 751(a) (6th ed. 1881).

26. E.g., Lanigan v. Lanigan, 78 So. $2 \mathrm{~d} 92$ (Fla. 1955) (remarriage plus delay of sixteen years amounted to laches); Langewald v. Langewald, supra note 24. Contra, Yost v. Yost, 161 Neb. 164, 72 N.W.2d 689 (1955) (under Uniform Divorce Recognition Act).

27. Chapman v. Chapman, 224 Mass. 427, 113 N.E. 359 (1916) (semble); Marvin v. Foster, 61 Minn. 154, 63 N.W. 484 (1895).

28. The leading case on the whole question of estoppel, Spellens v. Spellens, $49 \mathrm{Cal}$. $2 \mathrm{~d} 210,317$ P.2d 613 (1957), involved attack on a bigamous marriage, contracted before a prior marriage had been finally dissolved. See also Szlauzis v. Szlauzis, 255 I1l. 314, 99 N.E. 640 (1912) ; Rhodes v. Miller, 189 La. 288, 179 So. 430 (1938) (no estoppel); Rooney v. Rooney, 54 N.J. Eq. 231, 34 Atl. 682 (Ch. 1896) ; Landsman v. Landsman, 302 N.Y. 45, 96 N.E.2d 81 (1950), 51 CoLum. L. Rev. 388 (1951) (no estoppel); White v. Kessler, 101 N.J. Eq. 369, 139 Atl. 241 (Ch. 1927) ; Gress v. Gress, 209 S.W.2d 1003 (Tex. Civ. App. 1948) ; Martin v. Martin, 54 W. Va. 301, 46 S.E. 120 (1903) (no estoppel). See also Chafee, Some Problems of EQuity 75-77 (1950).

29. See, e.g., Starbuck v. Starbuck, 173 N.Y. 503, 66 N.E. 193 (1903) ; Stevens v. Stevens, 273 N.Y. 157, 7 N.E.2d 26 (1937) ; cf. Marvin v. Foster, 61 Minn. 154, 63 N.W. 484 (1895).

30. E.g., Romanski's Estate, 354 Pa. 261, 47 A.2d 233 (1946) ; Hamm v. Hamm, 30 Tenn. App. 122, 204 S.W.2d 113 (1947), 20 TeNn. L. Rev. 211 (1948), 1 VAND. L. Rev. 161 (1947); In re Englund's Estate, 45 Wash. 2d 708, 277 P.2d 717 (1954); In re Tamke's Estate, 32 Wash. 2d 927, 204 P.2d 526 (1949). 
present. If the action is "matrimonial," estoppel is said to be inappropriate, and the state's interest in regulating marriage dictates that the divorce without jurisdiction be held void. On the other hand, if the action is merely a "private" dispute over property, even though it may turn upon marital status, estoppel can apply. The New York courts, with an ingenuity which would be praiseworthy if employed in a socially useful cause, have succeeded in constructing upon this ostensibly simple distinction an edifice of inconsistency and confusion unsurpassed elsewhere in the law. Unfortunately for the rest of the nation, their decisions have had some influence in other states.

The distinction between "matrimonial" and "property" or "private" claims seems to have been first suggested in a short opinion by the New York Court of Appeals in Stevens v. Stevens, ${ }^{31}$ though not precisely in those terms. In that case the wife sued for a separation and the husband counterclaimed for a divorce on the ground of adultery. It appeared that the husband had already obtained a Nevada divorce, but it was conceded by both parties that the Nevada decree was without jurisdiction. The Court held that the husband was not estopped to assert Nevada's lack of jurisdiction even though he had obtained the divorce. The earlier case of Starbuck $v$. Starbuck, ${ }^{32}$ which held that a wife was estopped to attack a divorce which she herself had obtained and thus could not claim dower in the estate of her ex-husband, was distinguished as being a case "different in character." The two cases were in fact materially different. While in Starbuck the wife alone attacked the previously obtained divorce as invalid, in Stevens both husband and wife asked the court to disregard the earlier divorce and to assume the continued existence of the marriage. The wife in Stevens was in no position to invoke estoppel against her husband with respect to his counterclaim for divorce since she could hardly allege that the Nevada divorce was effective in barring any further action by her husband, but wholly inoperative as to her. The New York court, however, inexplicably chose to ignore this factual distinction, stating rather that in Starbuck the rejection of the wife's attack on the divorce she had obtained was "necessary in the due administration of justice," while in Stevens estoppel would not lie simply because the "court was invoked [sic] to pronounce directly upon the marital status-a relationship which no stipulation or conduct of the parties could alter."

The distinction inarticulately propounded in Stevens to explain what appeared to be an inconsistency in the two cases was described in more precise terms by the dissenting opinion in Krause v. Krause. ${ }^{33}$ In that case a second wife sued her husband for separation and support, after they had lived together about six years. The husband's defense was that the Reno divorce which he had obtained from his first wife was void for lack of jurisdiction,

31. 273 N.Y. 157,7 N.E.2d 26 (1937).

32. 173 N.Y. 503, 66 N.E. 193 (1903). The facts in this case provide the classic instance of estoppel. The court refuses to let a wife disavow her divorce in order to profit at the expense of the husband's second wife and the children of the second marriage.

33. 282 N.Y. 355,26 N.E.2d 290 (1940). 
so that he could not have been married to the plaintiff. The New York Court of Appeals held, however, that the husband could not thus avoid the responsibility which he voluntarily undertook. ${ }^{34}$ It specifically disavowed any recognition of the Reno divorce as valid, saying only that although it was invalid, he was estopped to attack it. It also made clear that the needs of the first wife would be taken into account in determining how much should be awarded to the second wife. The dissent, after a consideration of all the New York precedents, argued that they could be placed in two categories. The first group, including the Stevens case, were "matrimonial actions-cases that primarily involved a marital status asserted as such."35 Those cases, the dissent said, due to the public policy of the state, must declare the true status of the parties regardless of what hardship may result. The second group, including Starbuck, were "private suits" in which the claim-"though predicated on a marriage-was personal to an individual party." 36 In this second group of cases "equitable inducements conceived as affecting only the several parties to the litigation" could be considered by the courts. The dissenting judge thought, however, that the facts of the Krause case itself brought it into the first group of cases, those in which the court was bound to declare the true marital status irrespective of equitable considerations. Although the majority opinion did not discuss the dissent's characterization of the precedents, its holding that estoppel would be applied in an action for separation must certainly be construed as a refusal to embrace the matrimonial-private distinction, for if any action should be labeled "matrimonial" the action for separation should, as the dissenting opinion demonstrates.

Notwithstanding the majority's failure to approve the matrimonial-private distinction in the Krause case, the next case, Querze v. Querze, ${ }^{37}$ seemed to assume that this distinction was part of the law of New York, although such an assumption was not necessary to the decision. Querze summed up the prior cases as holding that one who obtains a foreign divorce is estopped to attack it in a private suit, but that he may have a full adjudication of his marital status in a matrimonial action. In this case a wife sued her husband for divorce and alimony. He defended on the ground of a Mexican mail-order divorce, which the wife had obtained several years before. This wife argued that this divorce was wholly void. The court held that she was not estopped to urge this, even though the husband had since remarried, because this was a matrimonial action. The claim for alimony did not transform it into a "private" suit, that claim being based upon statute, not the common law. Querze's characterization of the suit implies that the term "matrimonial" in New York

34. In the course of its opinion the court distinguished the Stevens case on the ground that there the husband was not really taking a position inconsistent with the Nevada decree, since in both Nevada and New York suits he was seeking to terminate the marriage. This distinction bears out the analysis suggested at notes $92-94$ infra.

35. 282 N.Y. 355, 361, 26 N.E.2d 290, 294 (1940).

36. Ibid.

37. 290 N.Y. 13, 47 N.E.2d 423 (1943). 
is to be defined as including all those actions conventionally referred to by that name, such as divorce, separation and annulment, and further that the inclusion of money claims in such suits does not alter their "matrimonial" nature. The matrimonial-private distinction is thus made to turn on commonly used labels, rather than on the remedy sought in the particular action. In this respect Querze is completely at variance with the decision in the Krause case. ${ }^{38}$

Perhaps the inconsistency in characterization between Krause and Querze is explicable on the basis of an exception when the divorce under attack is the mail-order variety. At any rate, it now seems to be true in New York that estoppel will not preclude attack on a Mexican mail-order divorce, whether or not the claim involved can be described as "private." The case which established this is Caldwell $v$. Caldwell, ${ }^{39}$ an action for separation brought by a second wife against her husband. He defended by attacking his Mexican mailorder divorce from his first wife as void, and on that premise argued that he

38. Krause v. Krause, 282 N.Y. 355, 26 N.E.2d 290 (1940). Estoppel was rejected in Lefferts v. Lefferts, 263 N.Y. 131, 188 N.E. 279 (1933), and in Fischer v. Fischer, 254 N.Y. 463,173 N.E. 680 (1930), both actions for separation. In Stevens v. Stevens, 273 N.Y. 157, 7 N.E.2d 26 (1937), also an action for separation, the court held it a "matrimonial" action, and thus not appropriate for estoppel. Yet a recent New York case seems to put annulment in the "private" category, where a wife was estopped to attack a Virginia divorce from her first husband and barred from annulling her second marriage. Packer v. Packer, 6 App. Div. 2d 464, 179 N.Y.S.2d 801 (1958). If annulment is not a "matrimonial" action, then the whole scheme of characterization has broken down. This case is in conflict with Landsman v. Landsman, 302 N.Y. 45, 96 N.E.2d 81 (1950), which held a husband could obtain an annulment where he has married before the decree annulling his wife's prior marriage had become final, even though he knew all the facts and persuaded his second wife to marry him. And Stewart v. Stewart, 188 Misc. 243, 67 N.Y.S.2d 799 (Supp. Ct. 1947) allowed estoppel in an action for divorce, implicitly standing for the proposition that divorce is "private."

Cases in other states have been more consistent in their characterization. Romanski's Estate, $354 \mathrm{~Pa} .261,47 \mathrm{~A} .2 \mathrm{~d} 233$ (1946) (dispute over inheritance held to be private); In re Tamke's Estate, 32 Wash. 2d 927, 204 P.2d 526 (1949) (same); Hamm v. Hamm, 30 Tenn. App. 122, 204 S.W.2d 113 (1947) (divorce action with no alimony claim held to be "matrimonial") ; Estate of Hensgen, 80 Cal. App. 2d 78, 181 P.2d 69 (1947) (dispute over appointment as administratrix of an estate held to be "matrimonial," but a later appeal of the same case held a dispute over the inheritance to be "private"); Hensgen v. Silberman, 87 Cal. App. 2d 668, 197 P.2d 356 (Dist. Ct. App. 1948), 21 So. Cal. L. Rev. 201 (1948), 22 So. Cal. L. Rev. 201 (1949).

39. 298 N.Y. 146, 81 N.E.2d 60 (1948), 47 MrCH. L. REv. 574 (1949); see Alfaro v. Alfaro, 5 App. Div. 2d 770, 169 N.Y.S.2d 943 (1958), 44 VA. L. REv. 1167 (1958); Vose v. Vose, 280 N.Y. 779, 21 N.E.2d 616 (1939); Marum v. Marum, 8 App. Div. 2d 975, 190 N.Y.S.2d 812 (1959); Whittleton v. Whittleton, 3 Misc. 2d 542, 152 N.Y.S.2d 117 (Sup. Ct. 1956). To the same effect are two cases applying New York law for the determination of social security claims. Magner v. Hobby, 215 F.2d 190 (2d Cir. 1954); Dwyer v. Folsom, 139 F. Supp. 571 (E.D.N.Y. 1956) (wife denied benefits after living with husband twenty-four years). A New York case which does reject attack on a Mexican mail-order divorce is Apelbaum v. Apelbaum, 7 App. Div. 2d 911, 183 N.Y.S.2d 54 (1959), but it may be explainable as applying New Jersey law, where the second 
had never married his second "wife." The court held that the estoppel of the Krause case could not be relied on where the divorce was by mail-order, since there was not the slightest semblance of jurisdiction in the Mexican court. Other sections of the opinion suggest that the real basis for this holding is that New York cannot tolerate an evasion of its own divorce laws so blatant (and so inexpensive) as that provided by the Mexican mail-order device. If even the limited effect provided by estoppel were conceded to such divorces, they might be frequently used, and New York's antiquated divorce laws would thereby be easily evaded. The same reasoning does not apply to the Reno divorce, which is relatively expensive, requires a stay of six weeks in Nevada, is beyond the reach of most New Yorkers, and thus offers less of a threat to New York's policies. ${ }^{40}$ Doctrines of divorce law which discriminate against the less well-to-do are, of course, no novelty.

It is clear that New York has both applied and rejected estoppel in identical types of cases, thereby proving that no criterion based upon the nature of the lawsuit is determinative in the use of the estoppel doctrine. In fact, the distinction between private and matrimonial actions as an explanation for the invocation of estoppel has not only failed of its purpose in New York (assuming what may be doubtful, that it ever existed there), but has actually increased the confusion. One thing can be said for the distinction, however. It has at last begun to focus courts' attention on the real source of the difficulty, a profound conflict in policies, a conflict whose ultimate outcome depends upon the changing attitudes toward divorce of both the public and the courts.

The traditional nineteenth century attitude toward divorce, which is still reflected in the law and the official pronouncements of New York and some other states, views divorce as a remedy provided exclusively for an innocent person whose spouse has been guilty of a serious marital wrong. ${ }^{41}$ Divorce

marriage occurred. It would seem, however, that the law of the forum or the domicile (both New York) should govern the application or nonapplication of estoppel here.

California has also vacillated in dealing with the question of estoppel to attack mailorder divorces. See Kegley v. Kegley, 16 Cal. App. 2d 216, 60 P.2d 482 (Dist. Ct. App. 1936) (held they could be attacked); Harlan v. Harlan, 70 Cal. App. 2d 657, 161 P.2d 490 (Dist. Ct. App. 1945) (held estoppel might apply); In re Shank's Estate, 154 Cal. App. 2d 808, 316 P.2d 710 (Dist. Ct. App. 1957) (same). The question now seems to be settled in favor of estoppel where the circumstances are appropriate. Rediker v. Rediker, 35 Cal. 2d 796, 221 P.2d 1 (1950); accord, Trivanovitch v. Hobby, 219 F.2d 762 (D.C. Cir. 1955) (applying Massachusetts law); Tonti v. Chadwick, 1 N.J. 531, 64 A.2d 436 (1949), 3 MIAAII L.Q. 629 (1949).

40. The analysis in the text is borne out by the fact that Mexican divorces can be the basis for an estoppel if one of the parties actually goes there, no matter how short his visit. Drew v. Hobby, 123 F. Supp. 245 (S.D.N.Y. 1954), granted social security benefits to a wife on the death of her second "husband," under circumstances almost exactly like those in Dwyer v. Folsom, 139 F. Supp. 571 (E.D.N.Y. 1956), the only difference being that in the Drew case one party to the marriage actually went to Mexico for a very short time, while in the Dwyer case the divorce was obtained by mail. See also Note, 47 Mich. L. REv. 574 (1949).

41. This is particularly true in New York, where only adultery is recognized as sufficiently serious to justify absolute divorce. N.Y. Crv. PRAC. ACT $\S 1147$. If both are 
itself is looked upon as evil, to be tolerated only in circumstances which strictly meet the statutory standard both as to grounds and as to the court's authority to act. ${ }^{42}$ The state has such an interest in preserving the marital relations of its citizens that any deviation from the strict standard may invalidate the resulting divorce; this both preserves the marriage with which the state is so concerned, and also serves as a warning to other erring spouses who might be tempted to evade the legal requirements. ${ }^{43}$ In this climate, any suggestion that the parties themselves attempted to procure a divorce by consent, without an occurrence of the required marital wrong, is especially likely to call forth bursts of righteous indignation from the courts. ${ }^{44}$ It is no wonder that with these premises a divorce obtained, for example, in Nevada upon a trumped-up residence and perfunctory proof of marital disagreement should be emphatically declared to be void, without regard to estoppel or other equitable factors. Nevertheless, many courts are doubtless aware that the positions which they defend so stoutly are no longer defensible. ${ }^{45}$

More modern authorities look upon divorce as a regrettable but necessary legal recognition of marital failure. ${ }^{46}$ It is recognized that very often, perhaps in most cases, the factors leading to breakdown of the marriage are not all on one side. ${ }^{47}$ Although the statutes rarely reflect this sociological view of di-

guilty, no divorce can be obtained. N.Y. Crv. Prac. Acr $\$ 1153(4)$. For an outline of grounds for divorce which bears out the text statement, see 2 VernIER, AMIERICAN Family Laws 3 (1931). But see Ploscowe, The Truth About Divorce 97-102 (1955). See also the new Wisconsin Family Code, which very largely adheres to the conventional attitude, especially, e.g., WIs. Star. ANN. \$ 247.101 (Supp. 1960).

42. Thus affirmative defenses may bar the divorce even though not pleaded by the defendant. See Annot., 76 A.L.R. 990, 1000 (1932) (collecting cases). See also note 4 supra.

43. See Hamm v. Hamm, 30 Tenn. App. 122, 204 S.W.2d 113 (1947), 20 TENN. L. REv. 211 (1948), 1 VAND. L. REv. 161 (1947); Graham v. Graham, 54 Wash. 70, 102 Pac. 891 (1909). The Uniform Divorce Recognition Act expresses this philosophy. See, e.g., Wis. Stat. AnN. § 247.22 (Supp. 1960).

44. E.g., Ainscow v. Alexander, 39 A.2d 54 (Del. Super. 1944); Smith v. Smith, 79 Mass. (13 Gray) 209 (1859) ; Hollingshead v. Hollingshead, 91 N.J. Eq. 261, 110 Atl. 19 (Ch. 1920). See also N.Y. DoM. REL. LAw $\$ 51$ (prohibits spouses from contracting to alter or dissolve their marriage).

45. See Ainscow v. Alexander, 39 A.2d 54, 61 (Del. Super. 1944), which concedes that the doctrines it enforces may be obsolete, but in familiar fashion places responsibility for changes upon the legislature.

46. Lichtenberger, Divorce-A SOCIAL InTERPRETATION 16 (1931).

47. Nimkoff, Contributions to a Therapentic Solution to the Divorce Problem: Sociology, U. Chi. Conf. on Divorce 55 (1952); Mead, Male and Fencale ch. XVII (1949); Sirjamaaki, The American Family in the Twentieth Century ch. 8 (1955); Waller, The Fammy chs. XX, XXI (1938); Mowrer, Family Disorganization (1927).

For a revealing discussion of the conflicting opinions on divorce in the modern world, see Report of the Royal Comamission on Miarriage and Divorce ch. 2 (1956); Pollard, The Problem of Divorce (1958). 
vorce, ${ }^{48}$ the practice in trial courts ${ }^{49}$ and the opinions of some appellate courts ${ }^{50}$ do. The doctrine of estoppel as applied in many jurisdictions also reflects this view, since it recognizes, at least for certain purposes, that a marriage has ended de facto and adjusts the legal rights and obligations of the parties accordingly, notwithstanding the fact that the termination of the marriage was not accomplished pursuant to prevailing legal requirements. ${ }^{.11}$ This has the effect, for most relevant purposes, of allowing the parties to end their marriage by consent, ${ }^{22}$ although courts often attempt to appease tradition by stating carefully that they are not validating a divorce without jurisdiction, but merely refusing to hear an attack upon it. ${ }^{53}$ This sort of distinction is of course familiar to lawyers, being similar to other ancient equity defenses, ${ }^{54}$ but we cannot expect laymen to understand it easily. It is therefore bound to create some confusion about the marital status of the parties, confusion which is highly undesirable. The uncertainty over whether parties are or are not married, or over whether they are married for some purposes, and if so, for what purposes, is a legitimate objection to the use of the estoppel theory. ${ }^{65}$ The refusal to rely on estoppel, however, may create even greater

48. A few states have adopted nonfault grounds for divorce. See, e.g., Colo. Sess. Laws 1958, ch. 37, S.S. 2 (three-year voluntary separation); N.M. STat. ANn. $\$ \S ~ 22-7-1$ (8) (1953) (incompatibility). Most retain the traditional grounds of adultery, cruelty, desertion, and the like.

49. See Ploscowe, The Truth About Drvorce (1955); Rheinstern, Our Dual Law of Divorce: The Law in Action Versus the Law of the Books, in U. Chr. Conf. on Drvorce 39 (1952); Alexander, A Therapeutic Approach, in U. Chr. Conf. on DIvORCE 51 (1952); Rheinstein, Trends in Marriage and Divorce Law of Western Conntries, 18 Law \& Contearr. Prob. 3 (1953).

50. E.g., De Burgh v. De Burgh, 39 Cal. 2d 858, 250 P.2d 598 (1952).

51. See, e.g., Goodloe v. Hawk, 113 F.2d 753, 757 (D.C. Cir. 1940) :

[I]t can no longer be said that public policy requires nonrecognition of all irregular foreign divorces. We have recognized that the interest of the state in many situations may lie with recognition of such divorces and preservation of remarriages rather than a dubious attempt to resurrect the original. From a pragmatic viewpoint, judicial invalidation of irregular foreign divorces and attendant remarriages, years after both events, is a less than ineffective sanction against an institution whose charm lies in its immediate respectability.

For somewhat similar views see also Rediker v. Rediker, 35 Cal. 2d 796, 221 P.2d 1 (1950); Cummings v. Huddleston, 99 Okla. 195, 226 Pac. 104 (1924).

52. See note 44 supra.

53. E.g., Spellens v. Spellens, 49 Cal. $2 d$ 210, 317 P.2d 613 (1957); Dietrich v. Dietrich, 41 Cal. 2d 497, 261 P.2d 269 (1953), cert. devied, 346 U.S. 938 (1954); Rediker v. Rediker, 35 Cal. 2d 796, 221 P.2d 1 (1950); Krause v. Krause, 282 N.Y. 355, 26 N.E.2d 290 (1940) ; Packer v. Packer, 6 App. Div. 2d 464, 179 N.Y.S.2d 801 (1958).

54. E.g., the historic doctrine that equity might enjoin as unconscionable the enforcement of a perfectly valid legal judgment. MaItLand, EQUITY 9 (2d ed. 1936).

55. Astor v. Astor, 6 Misc. 2d 967, 160 N.Y.S.2d 103 (Sup. Ct. 1957), is perhaps the most striking example of the uncertainty created by estoppel, since here the plaintiff was paying support money to two wives, and brought declaratory judgment suit to have his relationships cleared up. An unfeeling court denied relief. 
uncertainty. ${ }^{56}$ In any event, we are now so committed by the United States Supreme Court to a theory of "divisible divorce"57 that a large amount of uncertainty about the validity of divorces and ensuing marriages is inevitable.

One additional factor gives support to the estoppel doctrine. Protection of children is often said to be the strongest reason for a strict divorce law, and thus for what we have called the traditional nineteenth century attitude towards divorce. The assumption is that children are better off in the custody of two persons who remain married, albeit unhappily, than when they are placed in the custody of one or the other spouse upon the break-up of a marriage. In many of the estoppel cases, however, this harmful result is avoided, since one or the other of the parties has contracted a new marriage and the children can have a stable home, with both a mother and a father. This may be a further reason for the apparent willingness of courts to recognize a de facto marriage breakdown via the estoppel theory and to apply the analysis which we have suggested.

The estoppel doctrine thus represents an adherence to contemporary sociological theories of divorce, at the expense of the "conventional wisdom."58 Many states have made the choice readily and without serious reservation. Others, like New York, which is strongly committed by its statutes to traditional conceptions of divorce, have made it only reluctantly and with many a backward glance. This explains the confusion, the inconsistencies, the incomprehensible distinctions to be found in their decisions. As New York shows the same ambivalence about the ultimate goals of its divorce laws in other ways, ${ }^{\text {sn }}$ its treatment of estoppel is not surprising.

Notwithstanding the confusion, a principle is emerging from the cases which, with allowances for differences of approach, offers an explanation for the results reached and gives insight into the operative policies. It turns upon the conduct of the parties rather than the type of action. Three factors seem to be involved: 1) The attack on the divorce is inconsistent with prior conduct of the attacking party. 2) The party upholding the divorce has relied upon it, or has formed expectations based upon it. 3) These relations or expecta-

56. Dwyer v. Folsom, 139 F. Supp. 571 (E.D.N.Y. 1956) is an example. Here a woman was denied social security benefits after living with a man as his wife for twentyfour years. See also Cirone v. Cirone, 82 N.Y.S.2d 780 (Sup. Ct. 1948). In Alfaro v. Alfaro, 5 App. 2d 770, 169 N.Y.S.2d 943 (1958), 44 VA. L. REv. 1167 (1958), a marriage following a Mexican divorce was held void when the parties had lived as husband and wife for twelve years and had three children.

57. E.g., Estin v. Estin, 334 U.S. 541 (1948); Vanderbilt v. Vanderbilt, 354 U.S. 416 (1957).

58. Professor Galbraith's useful phrase. Galbratre, The Affluent Society 18 (1958).

59. Compare Shonfeld v. Shonfeld, 260 N.Y. 477, 184 N.E. 60 (1933), with Woronzoff-Daschkoff v. Woronzoff-Daschkoff, 303 N.Y. 506, 104 N.E.2d 877 (1952), on annulment for fraud. See Note, Anntlments for Frand-New York's Answer to Reno, 48 Colum. L. Rev. 900 (1948). See also Fisher v. Fisher, 250 N.Y. 313, 165 N.E. 460 (1929) (refusing to enforce New York's prohibition on remarriage after divorce); In rc Palmer's Estate, 192 Misc. 385, 79 N.Y.S.2d 404 (Surr. Ct. 1948) (same). 
tions will be upset if the divorce is held invalid. When either the first and third, or the second and third, of these factors exist, then one or the other or both of the parties have treated the marriage as at an end, and estoppel to attack the divorce amounts to recognition that such a marriage cannot be resurrected. All three factors will sometimes appear in a single case, making the nature of the situation particularly plain.

To put the principle in concise form, if the person attacking the divorce is, in doing so, taking a position inconsistent with his past conduct, or if the parties to the action have relied upon the divorce, and if, in addition, holding the divorce invalid will unset relationships or expectations formed in reliance upon the divorce, then estoppel will preclude calling the divorce in question.

Some cases have imposed an additional qualification on the use of estoppel. They reject estoppel where the party attacking the divorce was ignorant of the facts making the divorce invalid until a short time before bringing the suit to invalidate it. ${ }^{60}$ This qualification is based upon the traditional equity view of estoppel, rather than the social policy discussed in this article. It reflects some unwillingness to accept the implications of that policy and to that extent reveals a point of view opposed to the analysis advanced herein.

This additional qualification based on lack of knowledge of the divorce's defects aside, the differences between estoppel in divorce cases and the usual definition of equitable estoppel become clear. ${ }^{61}$ The social policy underlying equitable estoppel is the achievement of fairness and the prevention of fraud, ${ }^{02}$

60. This seems to have been the case in Smith v. Foto, 285 Mich. 361,280 N.W. 790 (1938) and Fischer v. Fischer, 254 N.Y. 463, 173 N.E. 680 (1930), in both of which second husbands were held entitled to upset divorces obtained by their wives from their first husbands. In neither case did the second husband know the circumstances of the divorce when he contracted the marriage. This fact distinguishes Fischer from Krause v. Krause, 282 N.Y. 355, 26 N.E.2d 290 (1940), where the husband was held estopped to attack his own divorce, and therefore liable to his second wife in her action for separation. The Krause opinion emphasized that the husband had voluntarily (i.e., knowingly) undertaken to support his second wife. In the Smith and Fischer cases the second husband had not undertaken this duty voluntarily in that sense of the word. See also Old Colony Trust Co. v. Porter, 324 Mass. 581, 88 N.E.2d 135 (1949); In re Gibson's Estate, 96 N.W.2d 859 (Wis. 1959). Jardine v. Jardine, 291 Ill. App. 152, 9 N.E.2d 645 (1937) is similar except that a second wife was suing for annulment, attacking her husband's Reno divorce.

Some cases do not insist on the limitation stated in the text. In Anderson v. Anderson, 121 Utah 237, 240 P.2d 966 (1952), a husband was held subject to an alimony decree arising out of a marriage clearly invalid because contracted before a prior divorce decree had become final. The ground for decision was the presumption that the later marriage was valid. Yet here the second husband was ignorant that the wife was not free to marry him. The effect was the same as if the husband had been held estopped. See also Bussey v. Bussey, 95 N.H. 349, 64 A.2d 4 (1949), where a wife was not allowed to make a direct attack on the divorce after the husband's remarriage, notwithstanding the lack of jurisdiction and that she moved immediately after she learned the facts.

61. See note 8 supra.

62. 3 Pomeroy, Equity Jurisprudence 179-84 (5th ed. 1941); 3 Story, EQuity JURISPRUDENCE 569-70 (14th ed. 1918). 
whereas here estoppel accomplishes the purposes of a contemporary theory of marriage and divorce. This illustrates both the use of old doctrine to serve new purposes and the value of equity as a reforming force in the law. ${ }^{63}$

The suggested analysis of estoppel places primary importance on the facts of each case. A close look at the facts of some representative cases will, therefore, give meaning to the analysis and perhaps eliminate some apparent inconsistencies. ${ }^{64}$ One fact of great importance to the application of estoppel is the remarriage of one or both of the parties to the void divorce. When this happens, the social purpose which has been advanced as the real basis for estoppel clearly demands recognition of the later marriage. Dietrich $v$. Dietrich ${ }^{65}$ is a good example. Here, in a separate maintenance suit by the wife, her husband alleged that her Nevada divorce from a prior husband was void. The court held that since the defendant had married the plaintiff with full knowledge of the circumstances in which she obtained her divorce, and had lived as her husband for many years, he was estopped to question her obviously invalid divorce. In this case the factors of inconsistent prior conduct, and reliance by the wife, were both present. There are two other interesting elements in the case. First, it was decided notwithstanding the provisions of the Uniform Divorce Recognition Act. ${ }^{66}$ Second, estoppel was applied in favor of the wife and against the husband even though the wife knew the circumstances of her own divorce, and presumably had the means of finding out that it was void. In other words, in this case no one was misled; the ground for estoppel was the reliance of both parties. ${ }^{67}$ This illustrates a commonly found difference

63. Maine, Ancient Law 27 (10th ed. 1884); Stone, Province and Function of LAW 459-63 (1950).

64. See the text discussion following note 32 supra, in which it is pointed out that in Stevens v. Stevens, 273 N.Y. 157, 7 N.E.2d 26 (1937), no elaborate distinction need be constructed to avoid using estoppel, since the necessary reliance was not present, and further, since both parties were attacking the divorce. Estoppel normally is resorted to where one party attacks the divorce, and the other party defends it or bases his claim upon it.

65. 41 Cal. 2d 497, 261 P.2d 269 (1953), cert. denied, 346 U.S. 938 (1954). See also Wendell v. Wendell, 111 Cal. App. 2d 899, 245 P.2d 342 (Dist. Ct. App. 1952); Norris v. Norris, 342 Mich. 83, 69 N.W.2d 208, cert. denied, 350 U.S. 903 (1955); Kelsey v. Kelsey, 204 App. Div. 116, 197 N.Y. Supp. 371 (1922), aff'd without opinion, 237 N.Y. 520, 143 N.E. 726 (1923); Cummings v. Huddleston, 99 Okla. 195, 226 Pac. 104 (1924). One case applies estoppel where the attack on the divorce came only two weeks after the former wife's remarriage, and where the wife had obtained the invalid divorce. Swift v. Swift, 239 Iowa 62, 29 N.W.2d 535 (1948).

66. Caz. CIv. Code ANN. $\$ 150.1$ : "A divorce obtained in another jurisdiction shall be of no force or effect in this State, if both parties to the marriage were domiciled in the State at the time the proceeding for the divorce was commenced." In Dictrich the parties were both domiciled in California when the Nevada divorce proceeding was begun. See also Langewald v. Langewald, 234 Mass. 269, 125 N.E. 566 (1920). Contra, Yost v. Yost, 161 Neb. 164, 72 N.W.2d 689 (1955).

67. Cf. Starbuck v. Starbuck, 173 N.Y. 503, 66 N.E. 193 (1903), where innocent third parties were misled. See note 32 supra. Some cases do emphasize the relative innocence of the parties, however. See Ex parte Nimer, 212 S.C. 311, 47 S.E.2d 716 (1948). 
between estoppel in divorce cases and the usual rules of equitable estoppel, since here the de facto marital relationship was the crucial factor, rather than unfair conduct by one party causing harm to another who was thereby misled.

The effect of a remarriage in a different context is shown by Marvin $v$. Foster. ${ }^{68}$ Here a husband deserted his wife and she divorced him, but the divorce was void for lack of proper service. The husband remarried, and on his first wife's death claimed a share of her estate, asserting the invalidity of the divorce. The court held he was estopped to do so, since such an attack would prejudice his innocent second wife and the child of the second marriage. A similar result was reached in Dennis $v$. Dennis ${ }^{69}$ where the husband got the void divorce, the wife knowing about it and accepting benefits under it. The husband then remarried, and the court held that the first wife was estopped to attack the decree by her receipt of benefits and by the husband's remarriage in reliance upon her apparent acquiescence.

The arguments supporting estoppel where there has been a remarriage are so strong that courts have been persuaded by them even where the divorce has been judicially held invalid, ${ }^{70}$ or where no final divorce had occurred at the time of the second marriage, ${ }^{71}$ or where the divorce was by mail-order, ${ }^{72}$ or

68. 61 Minn. 154, 63 N.W. 484 (1895).

69. 337 Mass. 1, 147 N.E.2d 828 (1958).

70. Brugviere v. Brugviere, 172 Cal. 199, 155 Pac. 988 (1916). Here the wife sued her first husband for separate maintenance. He defended on the ground of a Reno divorce. The wife had married a second husband in reliance on the Reno divorce, but had had this second marriage annulled in New York. The court held that the wife's acquiescence and reliance on the divorce precluded her from attacking it.

71. Spellens v. Spellens, 49 Cal. 2d 210, 317 P.2d 613 (1957); Smith v. Smith, 157 Cal. App. 2d 46, 320 P.2d 100 (Dist. Ct. App. 1958) ; Anderson v. Anderson, 121 Utah 237, 240 P.2d 966 (1952). Contra, Landsman v. Landsman, 302 N.Y. 45, 96 N.E.2d 81 (1950) (remarriage before the annulment became final).

72. Rediker v. Rediker, 35 Cal. 2d 796, 221 P.2d 1 (1950) (dictum); In re Shank's Estate, 154 Cal. App. 2d 808, 316 P.2d 710 (Dist. Ct. App. 1957) ; Hensgen v. Silberman, 87 Cal. App. 2d 668, 197 P.2d 356 (Dist. Ct. App. 1948); Harlan v. Harlan, 70 Cal. App. 2d 657, 161 P.2d 490 (Dist. Ct. App. 1945) ; Apelbaum v. Apelbaum, 7 App. Div. 2d 911, 183 N.Y.S.2d 54 (1959) (applying New Jersey law). In Astor v. Astor, 6 Misc. 2d 967, 160 N.Y.S.2d 103 (Sup. Ct. 1957) the husband had been held by a Florida court to be estopped to attack a Mexican divorce, and the New York court refused to terminate support payments he was required to make as a result of that estoppel. This amounts to a kind of second hand recognition of estoppel to attack Mexican decrees. Contra, that mail order divorces are not protected by estoppel : Magner v. Hobby, 215 F.2d 190 (2d Cir. 1954) (applying New York law); Garman v. Garman, 102 F.2d 272 (D.C. Cir. 1939) (no estoppel because no misrepresentation of facts to the Mexican court); Dwyer v. Folsom, 139 F. Supp. 571 (E.D.N.Y. 1956) (applying New York law); Kegley v. Kegley, 16 Cal. App. 2d 216, 60 P.2d 482 (Dist. Ct. App. 1936) ; Golden v. Golden, 41 N.M. 356, 68 P.2d 928 (1937) (parties actually visited Mexico for very short time); Caldwell v. Caldwell, 298 N.Y. 146, 81 N.E.2d 60 (1948), 47 MICH. L. Rev. 574 (1949); Querze v. Querze, 290 N.Y. 13, 47 N.E.2d 423 (1943) ; Whittleton v. Whittleton, 3 Misc. 2d 542, 152 N.Y.S.2d 117 (Sup. Ct. 1956). 
where there was no judicial divorce at all. ${ }^{73}$ These cases (the most numerous class in which estoppel is applied) lend additional force to the foregoing analysis of the social purpose involved in estoppel. They furnish an analogy to the well-established presumption that the latest of several marriages is valid. ${ }^{74}$ The presumption, though rebuttable, imposes a heavy burden of persuasion on the proponent of the earlier marriage. Like the doctrine of estoppel, it fulfills the legitimate expectations of the parties, and recognizes that a de facto marriage is entitled in most instances to legal protection.

A problem of priorities may sometimes arise as a result of estoppel. If the husband gets an ex parte Reno divorce from his first wife, under the case of Vanderbilt v. Vanderbilt ${ }^{75}$ she is still entitled to enforce her right to alimony if the law of the domicile recognizes a separate right to alimony. If he then should remarry, and his second wife should sue him for alimony or for separate maintenance, he would be estopped to attack the divorce, and would have to make support or alimony payments to the second wife also. This is substantially the Krause ${ }^{76}$ case, in which the court said that the needs of the first wife would be taken into account in arriving at the level of support for the second wife. The inference is that the first wife has a priority in the event that there is not enough income to go around. This seems sound if the second wife knew the facts when she married the husband. If she did not, it would seem that whatever was available should be divided between the two wives in accordance with their respective needs.

Often, no second marriage follows the void divorce. Nevertheless, the courts will usually refuse to hear an attack on the divorce if one or both parties have by their conduct given objective evidence that the marriage is at an end. If the wife accepts alimony or property pursuant to the invalid decree, she may not later attack it. ${ }^{77}$ The only thing accomplished by upsetting the divorce in

73. Shilman v. Shilman, 105 Misc. 461, 174 N.Y. Supp. 385 (Sup. Ct. 1918), aff'd 188 App. Div. 908, 175 N.Y. Supp. 681 (1919), aff'd 230 N.Y. 554, 130 N.E. 890 (1920) (Jewish "get" upheld on ground of connivance) ; Edgar v. Richardson, 33 Ohio St. 581 (1878). Norton v. Tufts, 19 Utah 470, 57 Pac. 409 (1899) held a first wife not estopped to attack a Mormon church divorce, though it contains language suggesting that such an estoppel might be raised under certain circumstances.

74. Apelbaum v. Apelbaum, 7 App. Div. 2d 911, 183 N.Y.S.2d 54 (1959) relies on both estoppel and the presumption as alternative grounds for decision. See also Anderson v. Anderson, 121 Utah 237, 240 P.2d 966 (1952).

75. 354 U.S. 416 (1957).

76. Krause v. Krause, 282 N.Y. 355, 26 N.E.2d 290 (1940), 27 VA. L. REv. 118 (1940), 18 N.Y.U.L. Rev. 94 (1941), 15 St. JoHN's L. Rev. 107 (1941). See also Astor v. Astor, 6 Misc. 2d 967, 160 N.Y.S.2d 103 (Sup. Ct. 1957), where the court refused to relieve the husband of the burden of supporting two wives, there being apparently sufficient income to take care of both.

77. Ferry v. Troy Laundry Co., 238 Fed. 867 (D. Ore. 1917) (wife estopped by receiving a property settlement as against a third party who relied on the husband's title); Anderson v. Anderson, 223 Ark. 571, 267 S.W.2d 316 (1954) (wife estopped by receiving a large sum under the decree); Oberstein v. Oberstein, 217 Ark. 80, 228 S.W.2d 615 (1950) (wife estopped by receipt of support under divorce); Green v. Green, 77 Ariz. 
this situation would be to enable the wife to extract more support from the husband or his estate, a reconciliation being the last thing on earth the parties desire. As the wife has generally been given all the alimony she is entitled to by the decree to which she objects, there is nothing to be gained by attempting to revive the defunct marriage. In such cases a further award subjects the husband to the hardship of an unforeseen liability; if the wife does have a legitimate claim for additional alimony she can usually, under the law of most states, move to have the decree modified by showing a change in her circumstances. ${ }^{78}$ Likewise, where the wife, although she receives no alimony under the void decree, waits for an unreasonably long time before attacking it, she should be estopped. ${ }^{79}$ If the husband obtained the divorce ex parte she can get her alimony by an independent suit where state law so provides. ${ }^{80}$ If, on the other hand, she sought alimony in the original suit and failed to get it, she should not be able to make a second attempt on her husband's pocketbook via an attack on the divorce decree, after a substantial time has passed and he has incurred other responsibilities. In fact, it would seem that if the wife once tried and failed to get alimony that should always conclude her alimony claim, whether or not the court had jurisdiction over the subject matter of the divorce. ${ }^{81}$ In any event, no useful purpose is served by allowing the wife to attack the divorce after any appreciable delay. ${ }^{82}$ The same is true when the attack is made by the husband, his motive usually being to establish a claim by way of inheritance against his former wife, ${ }^{83}$ or perhaps just to get revenge. ${ }^{84}$

No further discussion of estoppel as it rests upon prior inconsistent conduct (ordinarily upon the fact that the attacker himself got the divorce) is needed ${ }^{85}$ other than to say that here again insulating the decree sacrifices legal technicalities to the recognition of existing marital relationships. In cases of this kind the defendant in the first divorce action relies upon the divorce to form new relationships and to make new assumptions about his financial rights and duties. If the divorce is held invalid at the suit of the plaintiff in the first

219, 269 P.2d 718 (1954) (wife estopped by receipt of alimony, though husband got the divorce); Ellis v. White, 61 Iowa 644, 17 N.W. 28 (1883).

78. Cases are collected in Annots., 83 A.L.R. 1248 (1933); 127 A.L.R. 741 (1940); 18 A.L.R.2d 10 (1951). See also Desvernine, Grounds for the Modification of Alinony Awards, 6 Law \& Contearp. Prob. 236 (1939).

79. See cases collected in note 23 supra.

80. Vanderbilt v. Vanderbilt, 354 U.S. 416 (1957). See also Cooper v. Cooper, 314 Ky. 413, 234 S.W.2d 658 (1950). Presumably she would be required to act with reasonable diligence, however.

81. Cf. Note, Alintony After Foreign Decrees of Divorce, 53 HARv. L. REv. 1180 (1940).

82. Langewald v. Langewald, 234 Mass. 269, 125 N.E. 566 (1920) (wife trying to get more alimony after spending original award).

83. Cf. In re Feyh's Estate, 5 N.Y. Supp. 90 (Sup. Ct. 1889).

84. Swift v. Swift, 239 Iowa 62, 29 N.W.2d 535 (1948).

85. Cases are collected in note 13 supra. 
divorce action, these relationships and assumptions are upset, with consequent hardship to the divorce defendant, with undeserved benefit to the divorce plaintiff, and with no social advantage so far as restoration of the former marital relationship is concerned. In such circumstances the law is certainly justified in its reluctance to let a person change his mind and make claims which conflict with legal positions formerly taken. The Starbuck ${ }^{86}$ case illustrates this point. The wife got a void divorce in Massachusetts. The husband then remarried. After the husband's death the first wife asserted a claim to dower in his land on the theory that the divorce was void. The court held that she was precluded by the fact that she had gotten the divorce. As suggested, the same result should be reached where the wife obtains a divorce either with or without alimony and later attacks the divorce to recover support payments or a share in the husband's property. ${ }^{87}$

It must be conceded that there are cases which flatly reject both the doctrine of estoppel and the social policy which underlies it. ${ }^{88}$ They can only be accounted for as vestiges of an obsolete legal approach to marriage and divorce. There are other cases allowing attacks upon invalid divorces, however, which can be reconciled with the analysis we have been advocating. A brief examination of them may not only demonstrate this, but also clarify the analysis.

When a divorce is obtained without jurisdiction of the subject matter, and one of the parties remarries, he may be prosecuted for bigamy or bigamous cohabitation. In such a case estoppel is properly rejected, since the state is not subject to estoppel. ${ }^{89}$ Further, the aim of the bigamy statute is to punish just this kind of evasion of the legal technicalities prescribed for the ending of one marriage as a condition to the contracting of another. Some courts seem to think that refusing to recognize the second marriage is also an appropriate sanction against obtaining an invalid divorce in order to remarry. ${ }^{90}$ But criminal prosecution should be the only sanction, since it alone may be

86. Starbuck v. Starbuck, 173 N.Y. 503, 66 N.E. 193 (1903). A similar case involving a Mexican divorce is $I n$ re Shank's Estate, 154 Cal. App. 2d 808, 316 P.2d 710 (Dist. Ct. App. 1957). See also Romanski's Estate, $354 \mathrm{~Pa} .261,47$ A.2d 233 (1946) (the party getting the divorce was estopped to claim a share of the estate of his former spouse, no remarriage having occurred on either side); In re Tamke's Estate, 32 Wash. 2d 927, 204 P.2d 526 (1949) (same).

87. Oberstein v. Oberstein, 217 Ark. 80, 228 S.W.2d 615 (1950). But sce Lippincott v. Lippincott, 141 Neb. 186, 3 N.W.2d 207 (1942).

88. E.g., Magner v. Hobby, 215 F.2d 190 (2d Cir. 1954) (applying New York law to a Mexican mail-order divorce); Andrews v. Andrews, 176 Mass. 92,57 N.E. 333 (1900) (per Holmes, J.) ; Kiessenbeck v. Kiessenbeck, 145 Ore. 82, 26 P.2d 58 (1933) ; Gardner v. Gardner, 110 S.E.2d 495 (W. Va. 1959) (may turn on the private-matrimonial distinction).

89. People v. Chase, 27 Hun 256 (N.Y. Sup. Ct. 1882).

90. See Simmons v. Simmons, 19 F.2d 690 (D.C. Cir. 1927) (now overruled); Hollingshead v. Hollingshead, 91 N.J.Eq. 261, 110 At1. 19 (Ch. 1920); Kiessenbeck v. Kiessenbeck, 145 Ore. 82, 26 P.2d 58 (1933) ; cf. Hull v. Superior Court of Los Angeles, 352 P.2d 161, 167 (Cal. 1960) (in which the court states that "it is a degradation of marriage... when the courts use it as a device for punishment"). 
applied to the guilty party without running a risk of affecting the rights of innocent persons. Even the criminal sanction is not always applied with rigorous logic, however. There is a growing tendency for modern cases to say that a reasonable and good faith belief that an earlier marriage has ended in divorce will be a defense to a bigamy prosecution.91 This goes some of the way toward achieving the effects of a doctrine of estoppel. And the relative infrequency of bigamy prosecutions as compared with the number of invalid divorces testifies to society's lack of serious concern over people who obtain void divorces in divorce-mill states like Nevada.

Estoppel is also inappropriate in another class of cases illustrated by Garman v. Garman, ${ }^{92}$ Stevens v. Stevens, ${ }^{93}$ and Hamm v. Hamm. ${ }^{94}$ In all three cases an invalid divorce was upset at the instance of the person who had obtained it, after a rejection of claims of estoppel by the other party. This was a sound result in all these cases, however, because in none of them did invalidation of the divorce upset any relationships or expectations based upon it. All three were actions for divorce brought by the party who had originally obtained the invalid divorce, so that granting the divorce merely confirmed the putative existing relationship of the parties. No later marriages had occurred, and no financial claims were being made or extinguished. In the Hamm case the plaintiff-husband's claim for divorce was so far from injuring the wife that she did not even appear in the case, the defense of estoppel being raised by the divorce proctor. In all of these cases the result reached by rejecting estoppel gave legal recognition to the fact that the marriage had ended, at the same time settling any possible doubts about the parties' status, all of this without upsetting any expectations of either spouse. The moral is plain. When the goals of a modern divorce law can be reached by refusing estoppel, it will be refused. The important thing is the end, not the means. The result in these

91. The leading case is People v. Vogel, 46 Cal. 2d 798, 299 P.2d 850 (1956), 10 VaNd. L. Rev. 445 (1957), 45 Calif. L. Rev. 70 (1957). See Annot. 56 A.L.R.2d 915 (1957).

92. 102 F.2d 272 (D.C. Cir. 1939). It is significant that this case was not overruled by Goodloe v. Hawk, 113 F.2d 753, 757 (D.C. Cir. 1940).

93. 273 N.Y. 157, 7 N.E.2d 26 (1937) (husband counterclaiming for divorce, in a separation action brought by his wife).

94. 30 Tenn. App. 122, 204 S.W.2d 113 (1947), 20 TeNn. L. Rev. 211 (1948), 1 VAND. L. REV. 161 (1947). A slightly different case which may nevertheless be explained on the same grounds is Yost v. Yost, 161 Neb. 164, 72 N.W.2d 689 (1955), where a husband sued for divorce, and the wife defended on her prior Florida divorce. The husband was allowed to prove the Florida divorce invalid notwithstanding the wife's remarriage, the court relying on the Uniform Divorce Recognition Act. Neb. Rev. Stat. ANN. \& 42-341 (1943). But here again, the divorce in Nebraska would not upset any expectations of the wife based upon her Florida divorce, but would merely make it clear that she was free to remarry. At the most this would require a new ceremony of marriage to the second husband, though even this would not be necessary if the parties lived in a state recognizing common law marriage. What is most regrettable about the case is its reliance upon the wife's obtaining the Florida divorce as a reason for depriving her of custody of the child. 
cases is quite consistent with our definition of the estoppel principle, although they do not in terms rely on that principle.

Two questions are logically raised by our analysis of the estoppel doctrine. Should estoppel apply to Mexican mail-order divorces on the same terms as to other invalid divorces? And, what is more difficult, should the doctrine apply to a second "marriage," even though it was contracted before the parties had obtained any divorce, even an invalid one? The first question should certainly be answered affirmatively. Notwithstanding the New York cases there is authority which would go that far. ${ }^{05}$ The difference between spending forty-two days in Reno, or ninety days in Florida, and getting a divorce by mail from Mexico does not seem fundamental enough to justify an estoppel in the first two cases, and a denial of estoppel in the third, assuming that the facts bring the case in other respects within the principle we have described. If the states having strict divorce laws really are interested in preventing mail-order divorces, the criminal sanction is always available and is much more effective than a rejection of estoppel, which may affect innocent parties as seriously as guilty ones.

On the second question, too, one may find authority both ways. ${ }^{96}$ The issue commonly arises when a woman remarries before her divorce or annulment from her first husband is final. The second husband understands the circumstances, and may even go to some lengths to persuade her that there is no need to wait until the decree is final. Later the husband grows tired of his bargain and sues to annul. ${ }^{97}$ In states where common-law marriage is recognized, this relationship might ripen into a valid marriage by the mere passage of time, ${ }^{98}$ but this would not happen in states like New York ${ }^{99}$ or California ${ }^{100}$ which have abolished common-law marriage. If no estoppel is raised on these facts the husband is entitled to his annulment, and the wife has no claims for support or property. In New York this harsh result has been prevented by a statute which authorizes support awards in annulment cases as justice may require, ${ }^{101}$ and this may explain New York's refusal to hold the husband estopped.102 In other states which do not have this salutary statute estoppel

95. See cases cited in note 39 supra.

96. See Annot., Antemuptial Knowledge Relating to Alleged Grounds as Barring Right to Annulment, 15 A.L.R.2d 706 (1951) (collecting cases).

97. The facts stated were substantially those in Landsman v. Landsman, 302 N.Y. 45, 96 N.E.2d 81 (1950) ; Spellens v. Spellens, 49 Cal. 2d 210, 317 P.2d 613 (1957).

98. King v. King, 269 Ala. 468, 114 So. $2 d 145$ (1959); Boltz v. Boltz, 325 Mass. 726, 92 N.E.2d 365 (1950).

99. N.Y. Dom. ReL. LaW \& 11.

100. Cal. Crv. Cone ANn. $\$ 55$.

101. N.Y. Crv. Prac. Act $\$ 1140$-a (passed in 1940).

102. Landsman v. Landsman, 302 N.Y. 45, 96 N.E.2d 81 (1950). This case purported to rely on N.Y. Dom. REL. LAw $\$ 6$, which provides that a marriage is void if one of the parties has a living husband or wife by a former marriage, but the statute would seem to add nothing to the ordinary common law rule. The case contains no discussion of estoppel other than to say it does not apply here, conceding that the husband did not 
should be used as the rationale for protecting the wife. ${ }^{103}$ Denial of annulment would leave the parties, if their marriage had irretrievably broken down, to the remedy of divorce, in which the wife's financial claims could be honored. This same result is sometimes reached, even in New York, by imposing a heavy burden on the second husband to show that the first marriage has not ended in a divorce action brought by the first husband. 104 Here again the desire to recognize the expectations of the parties, frustrated by one doctrine, is given vent by another.

There remains for discussion the question whether, assuming that estoppel would preclude attack on an invalid divorce by one of the parties to the divorce action, the same doctrine would stand in the way of an attack by third persons. In many of the cited cases third parties were involved, but for clarity of analysis the question was postponed to this point. Before reaching this question two preliminary propositions must be established. The first is that the divorce decree, being traditionally in rem, has the same effect as other in rem decrees, that it conclusively adjudicates the termination of the marriage, not merely for the two parties, but for everyone. In the conventional phrase, it binds the whole world. Although there has recently been some skepticism about the in rem label in divorce actions, ${ }^{105}$ this proposition seems still to be correct. ${ }^{108}$

come into court with clean hands. The later case of Packer v. Packer, 6 App. Div. $2 d$ 464, 179 N.Y.S.2d 801 (1958) is entirely inconsistent in its reasoning with the Landsman decision, although the Appellate Division attempted to distinguish the cases on the ground that in Landsman the second spotse was plaintiff, while in Packer the action was brought by the party who had remarried in reliance on the divorce. See also Marrero v. Marrero, 183 N.Y.S.2d 685 (Sup. Ct. 1959). This assumes without discussion that remarriage by a divorced party estops him to attack the earlier divorce, while inducing such a remarriage with full knowledge of the facts does not estop the person doing so. This is an entirely insubstantial distinction. In both cases there is prior conduct consistent only with a valid divorce, and reliance on this conduct to form an attachment which is upset by the annulment. Estoppel should apply in both cases. See the New Jersey conflict between Freda v. Bergman, 77 N.J. Eq. 46, 76 Atl. 460 (Ch. 1910), and Rooney v. Rooney, 54 N.J. Eq. 231, 34 Atl. 682 (Ch. 1896).

103. Spellens v. Spellens, 49 Cal. 2d 210, 317 P.2d 613 (1957). Here the wife sued for separation, and the husband defended on the ground their marriage was void, but there should be no distinction from Landsman based on the form in which the action arose. The opinion in this case puts the policy basis of estoppel with clarity and vigor.

104. Apelbaum v. Apelbaum, 7 App. Div. 2d 911, 183 N.Y.S.2d 54 (1959) (alternative ground of decision).

105. Note, Stranger Attack on Sister-State Decrees of Divorce, 24 U. CHI. L. Rev. 376, 377 (1957) ; Ehrenzwerg, Conflict of Laws (pt. 1) 232 (1959).

106. Rediker v. Rediker, 35 Cal. 2d 796, 221 P.2d 1 (1950); Wilson v. Mitchell, 48 Colo. 454, 111 Pac. 21 (1910) ; Burlen v. Shannon, 69 Mass. (3 Gray) 387 (1855) ; In re Zeitz' Estates, 207 Misc. 22, 135 N.Y.S.2d 573 (Surr. Ct. 1954); Townsend v. Van Buskirk, 22 App. Div. 441, 48 N.Y. Supp. 260 (1897), appeal dismissed, 162 N.Y. 265,56 N.E. 837 (1900) ; Luick v. Arends, 21 N.D. 614, 132 N.W. 353 (1911); see RestateMrent, Judgrents $\$ 74$ (1942); 2 FreEMan, Judgarents $\$ 906$ (5th ed. 1925); cf. Williams v. North Carolina, 325 U.S. 226, 232 (1945). See also In re Uhrlaub's Estate, 99 N.Y.S.2d 
Secondly, the doctrine of estoppel will have no relevance to strangers unless they would otherwise be entitled to question the divorce for lack of jurisdiction over the subject matter. On this point the law is not clear, but there seems to be agreement that strangers have standing to attack the divorce collaterally under some circumstances. One view is that they may attack it only when the divorce has affected interests that were in existence before the divorce was granted. ${ }^{107}$ By this view a second husband could never question his wife's divorce from her first husband, since no preexisting interests would thereby be affected. ${ }^{108}$ The reason underlying this restricted rule is presumably that the divorce action did not injure the second husband in a way the law will recognize, even though the validity of the divorce controls the validity of the second marriage. If this is merely another expression of the social policy concerning divorce which has been urged as a support for estoppel, it is unexceptionable. ${ }^{109}$ As a description of the husband's interest it is, of course, false, since his marriage is entirely dependent upon the preceding divorce, this being a case where the validity of a judgment sharply affects interests created long after the judgment is given.

There is substantial other authority for a broader rule, that a third person may attack a divorce collaterally for lack of jurisdiction whenever it affects his rights or obligations, whether preexisting or not. ${ }^{110}$ In any event, both lines of authority raise in differing degrees the problem whether a third person, otherwise able to call the divorce in question, should be prevented from doing so by the doctrine of estoppel.

This problem most commonly arises when a man persuades a married woman to divorce her husband so that she will be free to marry him. He may even finance the divorce, provide a lawyer, or take an active part in other ways. When he does so, or even when he merely marries her with full knowledge of the circumstances surrounding the divorce, he is estopped to question the validity of the divorce. ${ }^{111} \mathrm{He}$ has engaged in conduct calculated to induce

456 (Surr. Ct.), aff'd without opinion, 277 App. Div. 1114. 101 N.Y.S.2d 938 (1950). Other cases are collected in Annot., 40 Axr. \& ENG. ANN. CAs, 875 (1916). It is usually held that the divorce decree does not establish, as against strangers, the existence of the marital status dissolved by the decree, however. See Annot., 20 A.L.R.2d 1163 (1951).

107. Weill v. Weill, 226 Ark. 206, 288 S.W.2d 946 (1956); Kieke v. Cox, 300 S.W.2d 309 (Tex. Civ. App. 1957) ; In re England's Estate, 45 Wash. 2d 708, 277 P.2d 717 (1954), 68 Harv. L. Rev. 1277 (1955) ; Crockett v. Crockett, 27 Wash. 2d 877, 181 P.2d 180 (1947). See also Annot., 12 A.L.R.2d 717, 723 (1950) (collecting cases); 1 FREEMAN, JUDGMENTS $\$ 319$ (5th ed. 1925) (same).

108. Weill v. Weill, 226 Ark. 206, 288 S.W.2d 946 (1956) ; Gaylord v. Gaylord, 45 So. 2d 507 (Fla. 1950).

109. See the discussion at note 58 supra.

110. The leading case for this view is Old Colony Trust Co. v. Porter, 324 Mass. 581, 88 N.E.2d 135 (1949). See also Annot., 12 A.L.R.2d 717, 723, 733 (1950) (collecting cases).

111. E.g., Goodloe v. Hawk, 113 F.2d 753 (D.C. Cir. 1940) ; Dietrich v. Dietrich, 41 Cal. 2d 497, 261 P.2d 269 (1953), cert. denied, 346 U.S. 938 (1954); Zirkalos v. Zirkalos, 326 Mich. 420, 40 N.W.2d 313 (1949). 
reliance on the divorce, and indeed, he has relied on it himself. Therefore, the reasons of policy which prevent attack by a party to the divorce action are equally persuasive here. Some cases have said, however, that if he marries without knowledge of the circumstances in which the divorce was obtained he is not estopped to attack it when he later learns the facts. ${ }^{112}$ These cases represent an adherence to the traditional view of equitable estoppel, and a reluctance squarely to face the social policies involved in this situation. Here, as in other cases where estoppel is asserted, the invalidity of the divorce is really irrelevant to the interests of the second spouse. But the force of the older notions of good faith and innocence inhering in all equity doctrines is so strong that it is not surprising to find cases which refuse to apply estoppel in these circumstances.

Although the party contesting the validity of the divorce did not himself act so as to create an estoppel, he is still precluded from attacking it if his claim is derived from a person who would have been estopped.113 Thus, the child of the first marriage may try to upset the divorce after his father's death in order to prevent the second wife from taking a share of the husband's estate. If estoppel rests on a recognition of the de facto existence of the second marriage it should bar attack by the child in this case, at least where the husband would have been barred. The second wife did rely on the divorce, whether or not she knew the facts, and no social purpose is served by denying her a share in the estate. A few cases do refuse to protect her, however, either on the ground that the child's claim is not derivative, ${ }^{114}$ or on the ground that both husband and second wife knew the divorce was invalid. ${ }^{115}$ If the dispute is between the first and second wives, and the first has done nothing to induce reliance upon the divorce, then she or persons claiming under her are not estopped to prove that the divorce was granted without jurisdiction.116 Again, this aspect of the case law amounts to an unwarranted survival of conventional equitable estoppel doctrine.

The social security cases are sui generis. Although technically the parties involved are the claimants and the United States, and although estoppel does

112. Smith v. Foto, 285 Mich. 361,280 N.W. 790 (1938); Fischer v. Fischer, 254 N.Y. 463,173 N.E. 680 (1930); cf. note 60 supra. See also Old Colony Trust Co. v. Porter, 324 Mass. 581, 88 N.E.2d 135, 141 (1949).

113. E. g., In re Brandt's Estate, 67 Ariz. 42,190 P.2d 497 (1948) ; Kelsey v. Miller, 203 Ca1. 61, 263 Pac. 200 (1928).

114. In re Lindgren's Estate, 293 N.Y. 18, 55 N.E.2d 849 (1944).

115. Ex parte Nimmer, 212 S.C. 311,47 S.E.2d 716 (1948). The husband's father and the wife here sought letters of administration in the husband's estate. The court gave a decree for the father, saying the wife's hands were unclean, since she and the husband had both participated in a fraud in getting an invalid divorce. The court in effect punishes the wife by excluding her from a share in the estate. Oddly enough no mention is made of the presumption that the later marriage is valid. The reasoning in the case is less than convincing. Accord, Ainscow v. Alexander, 28 Del. Ch. 545, 39 A.2d 54 (Super. Ct. 1944).

116. Brandt v. Brandt, 76 Ariz. 154, 261 P.2d 978 (1953); see text accompanying notes $60 \& 112$ supra. 
not run against the government, the federal courts have attempted to look at the rights and disabilities, including estoppel, of the persons claiming benefits in the light of the applicable state law. Where, under that law, a prior spouse would be estopped to attack the divorce, she is also estopped to claim social security benefits as a surviving widow. ${ }^{117}$

Estoppel, or quasi-estoppel, as some cautious courts prefer it, has been shown to be approved by the great majority of courts. It rests not upon vague notions of fairness or equity or relative rectitude of the parties, and not upon the dubious distinction between private and matrimonial lawsuits, but rather upon the contemporary view that when a marriage has ended, and its end has been recognized by divorce, little is to be gained by treating it as if it were still in force. To this social purpose, and to the doctrine of estoppel itself, therefore, there can hardly be serious objection.

117. Awarding benefits to the later spouse on the theory of estoppel: Trivanovitch v. Hobby, 219 F.2d 762 (D.C. Cir. 1955) (under Massachusetts law); Drew v. Hobby, 123 F. Supp. 245 (S.D.N.Y. 1954) (New York law). Rejecting estoppel: Magner v. Hobby, 215 F.2d 190 (2d Cir. 1954) (Mexican mail-order divorce, void under New York law); Dwyer v. Folsom, 139 F. Supp. 571 (E.D.N.Y. 1956) (New York law). 


\section{THE YALE LAW JOURNAL}

\begin{tabular}{lll}
\hline Volume 70 & NOVEMBER 1960 & NuMber 1
\end{tabular}

\section{ROBERT E. HUDEC \\ Editor-in-Chief}

Neale M. Albert

LAWRENCE G. Goodman

David M. TRUBeK

JERE A. Young

Note \& Conment

Editors

\author{
Harrison J. Goldin \\ Article \& Book \\ Review Editor
}

SIDNEY M. WoLINSKY

Topics \& Case

Editor

Peter R. TAFT

Managing Editor

Hershel Y. Allerhand

Thomas B. Bracken

Carroll W. Brewster

Alan M. Dershowitz

JAN Deutsch

George DrIesen
Benjamin S. DuVai, Jr. David I. GoldblatT

Wirlians S. GreEnawalt

David C. Greer

Arthur P. JACOBS

ROBERT A. JoHNSON

LAWRENCE P. KIAMSON
ZANE KIEIN

Cinarles E. Lewis

James L. Mitchell

Stoddard D. Platt

Daytd A. Rosen

AdaM WaIINSKY

Marie McMaton

Business Secretary

\section{CONTRIBUTORS TO THIS ISSUE}

Wrluram O. Dougras. A.B. 1920, Whitman College; LL.B. 1925, Columbia University. Associate Justice, United States Supreme Court.

Harold WuRzec. LL.B. 1939, Columbia University. Member of the New York Bar; Editor, The Research Institute of America, Inc.

Homer Clark. A.B. 1939, Amherst College; LL.B. 1942, IL.M. 1952, Harvard University. Professor of Law, University of Colorado.

RALPH K. WINTER. A.B. 1957, LL.B. 1960, Yale University. 